\title{
Perioperační léčba bolesti
}

\author{
Jiří Málek \\ Klinika anesteziologie a resuscitace 3. LF UK a FNKV, Praha
}

Řada studií prokázala, že asi třetina pacientů má po operaci epizody silné až kruté bolesti. Základním principem úspěšné léčby je měření intenzity bolesti a výsledku terapie. Cílem multimodální analgezie je dosáhnout adekvátní úlevy od bolesti s minimem vedlejších účinků léčby, zejména nežádoucích účinků opioidů. Metaanalýzy potvrzují, že mezi nejčastější a nejbezpečnější neopioidní analgetika patří paracetamol a metamizol, nesteroidní analgetika nejsou obecně v perioperačním období vhodná, protože mají zvýšené riziko vlastních nežádoucích účinků, jako je závažné pooperační krvácení, nebo u některých renální selhání. Velký význam v terapii akutní i chronické bolesti získává ketamin. Ostatní často studované látky s výjimkou systémového podávání lidokainu nemají dostatečně prokázanou účinnost. Zejména jde o gabapentinoidy, které by se jako adjuvantní léčba při perioperační analgezii neměly používat vůbec. Základem léčby silné pooperační bolesti zůstávají opioidy, i když je trvalá snaha jejich používání snižit na minimum. Vyvíjejí se nové opioidy, nebo se upravují staré molekuly s cílem prodloužit jejich účinek (morfin, bupivakain), rozvíjejí se metody pacientem kontrolované analgezie. Důležitou součástí multimodální analgezie jsou lokální anestetika. Od konce 20. století je zaznamenán postupný přechod od neuroaxiálních metod aplikace ke stále perifernějším blokádám, až po lokální jednorázovou či kontinuální infiltraci operační rány.

Klíčová slova: multimodální analgezie, neopioidní analgetika, nesteroidní antiflogistika, opioidy, ketamin.

\section{Perioperative pain management}

Many studies demonstrated that the treatment of postoperative pain is still suboptimal and approximately one third of patients after surgery suffer from strong or sever pain. Essential part of successful therapy is measurement of intensity of pain and the effect of analgesic therapy. Multimodal analgesia is used do decrease side effects of individual drugs, mainly opioids. The results of meta-analyses confirm that the most frequently used and the safest analgesics are paracetamol and metamizol (dipyrone). Non-steroidal anti-inflammatory drugs are not recommended, because of their potentially serious side effects like postoperative bleeding or in some drugs renal failure. Important role in the treatment of acute and chronic pain has ketamine. Other adjuvant drugs have not proved their efficacy except of systemic lidocaine; gabapentinoids should not be used in this indication at all. Opioid therapy remains the cornerstone of postoperative pain treatment. There are some new opioids under development or new modification of old molecules mainly to prolong their effect (morphine, bupivacaine); new methods of patient controlled analgesia are used. Very important component of multimodal analgesia are loco-regional methods. Recent trend is changing strategy of administration of local anaesthetics from centre to periphery: from epidural catheters to more peripheral blocks and finally to single shot or continuous local infiltration.

Key words: multimodal analgesia, non-opioid analgesics, non-steroidal anti-inflammatory drugs, opioids, ketamine.

\section{Úvod}

Objev éterové anestezie ukončil muka pacientů, kteří byli operováni většinou při plném vědomí, a rozsah jejich utrpení záležel prèevev̌̌im na rychlosti operatéra. To, že samotná operace proběhla bez vnímání bolesti, vedlo k nadšeným článkům, které se shodovaly na tom, že bolest z chirurgie konečně zmizela. Napríklad krátce po prvých operacích s použitím éteru ve Velké Británii London People's Journal napsal velkými písmeny: „BOLEST BYLA PORAŽENA“ (1). Později někdo ze současníků vtipně poznamenal, že pa- cienti po operaci byli jiného mínění. Názor lékařů, že pooperační bolest k chirurgii patří, přetrvával poměrně dlouho. Léčba morfinem u pacientů po operacích začala být široce používána až během první světové války, ale systematický prístup k terapii akutní pooperační bolesti (APB) začíná 
až v 90. letech 20. století. Od té doby prošel přístup k APB několika obdobími. Na začátku byla v popředí snaha o zviditelnění problému nedostatečně léčené akutní bolesti, především bolesti pooperační. Výsledkem byla iniciativa vyhlášení akutní pooperační bolesti za pátou vitální funkci a implementace postupů léčby APB do dokumentace zdravotnických zařizení jako podmínky akreditačního řízení $(2,3)$. Výsledkem byl predevším v USA strmý vzestup předepisovaných opioidů nejen na chronickou, ale i akutní bolest včetně bolesti pooperační. Pacienti byli propouštěni z nemocnice s počtem dávek opioidů podstatně převyšujících jejich potřebu, což vedlo ke zvýšení počtu osob psychicky závislých na opioidech a k nárůstu úmrtí v souvislosti s jejich zneuživáním (4). I když varování se objevila již záhy počátkem tohoto století, farmaceutické firmy dále propagovaly masové používání opioidů. V roce 2007 byla firma Purdue Frederick Company, Inc. odsouzena za klamavé informace týkající se proklamované bezpečnosti $10 \mathrm{mg}$ tablet Oxy-Continu k zaplacení 634,5 milionu dolarů $(5,6)$. Druhé desetiletí 21. století je v tomto ohledu charakterizováno celou řadou iniciativ k omezení používání opioidů včetně hledání snah, jak je nahradit. Nejčastěji se v USA píše o léčebném konopí a ketaminu.

Snahy o omezení používání opioidů k léčbě akutní (i chronické, což ale není obsahem tohoto sdělení) bolesti vedly k rozšíření palety léků a postupů ve formě multimodální analgezie. Poslední čtvrtstoletí bylo svědkem vzestupu a ústupu několika témat, jako je preemptivní analgezie, opioidy indukovaná hyperalgezie a chronická pooperační bolest. Zvyšující se dostupnost a kvalita ultrazvukových prístrojů změnily možnosti lokoregionálních metod analgezie, nové př́stroje umožnily pacientům samostatné dávkování opioidů (pacientem kontrolované analgezie - P(A) neinvazivním prístupem. Objevily se injekční preparáty s dlouhodobým účinkem (lipozomální bupivakain a morfin).

\section{Měření intenzity bolesti}

Všechna doporučení se shodují v tom, že nelze kvalitně léčit APB bez měření její intenzity pred a po léčbě $(7,8)$. Bolest je vždy subjektivní, ale pro praktické účely komunikace je nutné ji objektivizovat. U dospělých se nejčastěji používají verbální popisy (bolest žádná, mírná, střední, silná, krutá - nesnesitelná), nebo numerická škála (numeric rating
Obr. 1. Pomůcka k měření intenzity bolesti vizuální analogovou škálou a) líc b) rub

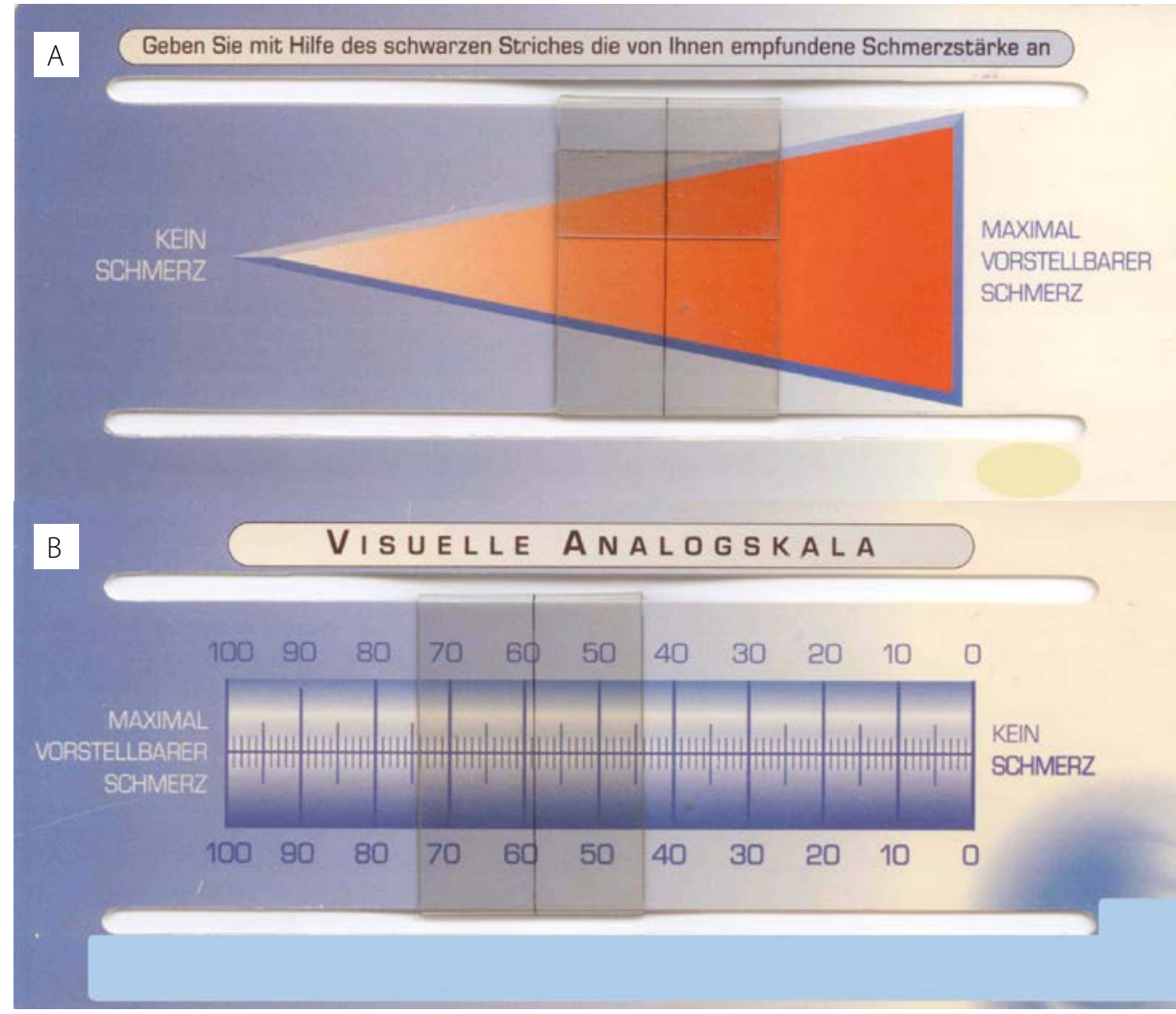

Obr. 2. Obličejová škála pro měrení intenzity bolesti ( 0 - bez bolesti, 2 - mírná bolest, 4 - snesitelná bolest, 6 - silná bolest, 8 - krutá bolest, 10 - nesnesitelná bolest)
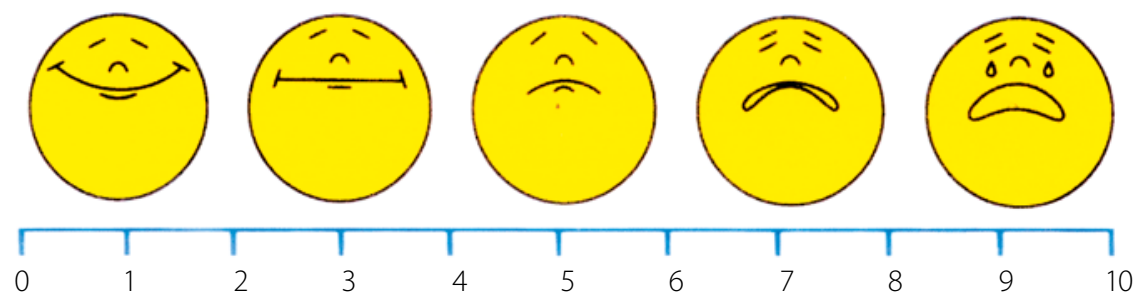

scale - NRS) 0-10 (nebo 100), kde krajní body predstavují žádnou a nejsilnější možnou predstavitelnou bolest. Vizuální analogová škála (VAS) pakje z pacientovy strany bez čísel, ze strany určené pro zdravotníka je pak NRS (obrázek 1a, b). I když na prvý pohled se zdá, že jde o škály lineární, různé studie prokázaly, že by po operaci maximální hodnota NRS, na kterou je třeba terapeuticky reagovat, neměla převýšit hodnotu 4 (u verbálního hodnocení maximálně mírná bolest). U osob, které nejsou schopny verbálně komunikovat (mentálně handicapovaní, malé děti), se používají rưzné obrázky výrazů obličeje (obrázek 2), prípadně škály využívající objektivní parametry (puls, krevní tlak, saturace krve kyslíkem) v kombinaci s hodnocením pozorovatele (svalový tonus, výraz tváře, spánek, apod.), např́klad skóre PAINAD, CRIES, COMFORT, CHEOPS, POPSI. Detailní popis je mimo rozsah tohoto článku, Ize odkázat na dostupnou literaturu (9).

\section{Teoretická východiska terapie}

Pooperační bolest je kombinací senzorické odpovědi na zánětlivé změny a bolesti z poškození nervových struktur, príčemž vzorec je odlišný podle toho, zda jde o chirurgické trauma kůže, svalů či viscerálních orgánů. Poškozením tkáně dochází na periferii k uvolnění zánětlivých a proalgických mediátorů, jejichž výsledkem je spontánní aktivita nocisenzorů v C vláknech, mechanická a termická hyperalgezie (snížení prahu bolesti) a alodynie (pocit bolesti při jinak nebolestivém podnětu). Bylo zjištěno, že je rozdíl mezi aktivací nocisenzorů ve svalech a v kưži (10). V oblasti zadních rohů míšních dochází k aktivaci pronociceptivních receptorů. N-methyl-D-aspartátové (NMDA) receptory mají zpočátku menší roli než se myslelo. Dřive dochází k aktivaci receptorů AMPA (pojmenovaných podle agonisty alfa-amino3-hydroxy-5-methyl-4-isoxazolepropionové kyseliny - alpha-amino-3-hydroxy-5-methyl-4isoxazolepropionic acid), a to již za méně než 


\section{HLAVNÍ TÉMA}

12 hodin po chirurgickém traumatu. Výsledkem je rozšîrení receptorového pole pro algické podněty z periferie a vznik centrální senzitizace. Změny $\checkmark$ mozku jsou zatím nejméně prozkoumané. Podle dosavadních výzkumů se zdá, že klíčovou roli hraje thalamus, který má raadu dalších spojů do CNS. Pomocí funkční magnetické rezonanční spektroskopie bylo v thalamu zjištěno zvýšení koncentrací kyseliny gama-aminomáselné (GABA) a potlačení descendentních inhibičních drah. Konečně recentní experimenty na zviŕratech prokazují dlouhodobé epigenetické změny spojené s modulací metylace DNA, acetylací histonů a změn kódování RNA, což je jedno z možných vysvětlení chronifikace akutní bolesti $(9,10)$.

Tyto patofyziologické mechanismy jsou důležité pro strategii léčby $A P B$, zejména pro koncepci multimodální analgezie.

\section{Hlavní principy per- a pooperační analgezie}

Pooperační léčba bolesti začíná anesteziologickým plánem ještě před operací výběrem vhodného typu anestezie s ohledem na rozsah operace a následné analgetické metody. Vysoké dávky opioidů již během operace mohou vést k rozvoji opioidy navozené hyperalgezie - stavu zvýšené intenzity APB a spotřeby analgetik; nejČastěji se jedná o vysoké dávky remifentanilu (11, 12). Prevencí může být použivání přiměřených dávek opioidů během operace, současné podávání propofolu, pravděpodobně i ketaminu a oxidu dusného (12). Strategie léčby spočivá v pravidelném sledování intenzity bolesti, účinků terapie a individualizace léčby podle potřeb pacienta. Použivá se multimodální analgezie, při intenzivní bolesti se začíná potentními analgetiky (nejčastěji opioidy) v dostatečných dávkách a tak, jak se intenzita bolesti snižuje, Ize přecházet k neopioidním analgetikưm a perorálním formám podání („sestup po analgetickém žebřičku“).

\section{Multimodální analgezie}

Volba pooperační analgezie se odvíjí od předpokládané intenzity bolesti ( $v$ angličtině procedure specific analgesia) (Tabulka 1). Základem moderních postupů je multimodální analgezie - kombinace postupů a léků z různých skupin s cílem minimalizovat jejich jednotlivou dávku a potencovat analgetický efekt. Jedním z hlavních cílů multimodální analgezie je snížit nežádoucí účinky opioidů (sedace, nevolnosti

Tab. 1. Doporučení České společnosti anesteziologie, resuscitace a intenzivnímedicíny k léčbě pooperační bolesti - modifikováno podle (29)

\begin{tabular}{|l|l|}
\hline $\begin{array}{l}\text { Operace s předpokladem mírné bolesti } \\
\text { př́klad: artroskopie, endoskopické urologické } \\
\text { výkony, malé gynekologické výkony, povrchní kožní } \\
\text { operace, malé výkony v ORL }\end{array}$ & $\begin{array}{l}\text { Infiltrace rány LA, neopioidní analgetika + NSA* } \pm \\
\text { jednorázově opioidy dle potřeby }\end{array}$ \\
\hline $\begin{array}{l}\text { Operace s předpokladem střední až silné bolesti } \\
\text { príklad: endoskopické abdominální a nitrohrudní } \\
\text { operace, trríselná kýla, hysterektomie, ablace prsu, } \\
\text { operace strumy }\end{array}$ & $\begin{array}{l}\text { Infiltrace rány LA, neopioidní analgetika + NSA } \pm \\
\text { opioidy pravidelně }\end{array}$ \\
\hline $\begin{array}{l}\text { Operace s předpokladem silné až kruté bolesti } \\
\text { př́klad: otevřená torakotomie, břišní výkony v } \\
\text { epigastriu, totální náhrady kolenního kloubu, } \\
\text { nefrektomie, operace skolióz }\end{array}$ & $\begin{array}{l}\text { Infiltrace rány LA, systémové opioidy (PCA) } \pm \\
\text { neopioidní analgetika, NSA } \pm \text { adjuvancia } \\
\text { Lokoregionální metody s LA + opioidy + systémová } \\
\text { neopioidní analgetika } \pm \text { NSA } \pm \text { adjuvancia }\end{array}$ \\
\hline
\end{tabular}

LA - lokální anestetika, NSA - nesteroidní antiflogistika, PCA - pacientem kontrolovaná analgezie

* Neselektivní NSA se nedoporučují u výkonů ORL a dalších operacís rizikem krvácení

Tab. 2. Nejčastěji použivané léky k léčbě pooperační bolesti a jejich dávkování - modifikováno podle $(9,16,30)$

\begin{tabular}{|c|c|}
\hline \multicolumn{2}{|c|}{ Neopioidní analgetika } \\
\hline Paracetamol & $\begin{array}{l}\text { Od } 3 \text { měsíců p.r*., p.o. děti 10-15 mg/kg, dospělí 15-20 mg/kg, } \\
\text { i.v. dávkování (16) } \\
\text { děti do } 10 \text { kg: 7,5 mg/kg, } 10 \text { až } 33 \text { kg: } 15 \text { mg/kg, max. } 2 \text { g/den, } 33 \text { až } 50 \text { kg: } 15 \text { mg/ } \\
\text { kg: max. } 3 \text { g/den (i dospělí pod } 50 \text { kg) } \\
\text { Dospělí nad } 50 \text { kg: max. } 4 \text { g/den }\end{array}$ \\
\hline Metamizol & $\begin{array}{l}\text { Od } 3 \text { měsíců i.m., od } 1 \text { roku i.v. v pomalé infuzi 6-16 mg/kg, u dospělých max. } \\
1-2 \text { g pro dosi, max. } 5 \text { g/den, ne ve 3. trimestru gravidity }\end{array}$ \\
\hline \multicolumn{2}{|c|}{ Nesteroidní antiflogistika** } \\
\hline Diklofenak & $\begin{array}{l}\text { Jen u dospělých; i.m., i.v. v dlouhodobé infuzi } 75 \text { mg max. 2x denně***, od } 15 \text { let } \\
\text { p.o. 25-100 mg, max. } 150 \text { mg/den. }\end{array}$ \\
\hline Ibuprofen & $\begin{array}{l}\text { Od } 3 \text { měsíců p.o., p.r. 20-35 mg/kg, u dospělých 400-800 mg p.o., max. 2,4 g/den, } \\
\text { i.v. v pomalé infuzi jen u dospělých } 400 \text { mg, max. 1,2 g/den }\end{array}$ \\
\hline Ketoprofen & Od 15 let i.m. nebo v pomalé infuzi 100 mg, max. 200 mg/den \\
\hline Parecoxib & i.v., i.m. 40 mg, max. 80 mg/den, jen u dospělých, ne u kardiochirurgických operací \\
\hline \multicolumn{2}{|l|}{ Slabé opiody } \\
\hline Tramadol & od 1 roku p.o., i.v., i.m. 1-2 mg/kg po 4-6 hod., maximálně 400 mg/den \\
\hline \multicolumn{2}{|l|}{ Silné opioidy } \\
\hline Morfin & i.m., s.c., i.v. 0,1 mg/kg (i.v. frakcionovaně), denní dávka individualizovaně \\
\hline Piritramid & $\begin{array}{l}\text { i.m., s.c. u dospělých } 15-30 \text { mg, u dětí 0,05-0,2 mg/kg, i.v. velmi pomalu } \\
\text { frakcionovaně } 7,5-22,5 \text { mg u dospělých, 0,05-0,1 mg/kg u dětí }\end{array}$ \\
\hline Fentanyl & i.v. individualizovaně, bolus 1-3 $\mu \mathrm{g} / \mathrm{kg}$, kontinuálně $1-2 \mu \mathrm{g} / \mathrm{kg} / \mathrm{h}^{* * * *}$ \\
\hline Sufentanil & i.v. individualizovaně, bolus $0,1-0,5 \mu \mathrm{g} / \mathrm{kg}$, kontinuálně $0,2-1 \mu \mathrm{g} / \mathrm{kg} / \mathrm{h}^{* * * *}$ \\
\hline \multicolumn{2}{|c|}{ Celková anestetika } \\
\hline Ketamin & i.v. $1-2 \mathrm{mg} / \mathrm{kg} / 24$ hod. \\
\hline \multicolumn{2}{|c|}{ Lokální anestetika } \\
\hline Bupivakain & $\begin{array}{l}\text { Infiltrace rány bolus maximálně } 2 \mathrm{mg} / \mathrm{kg} \\
\text { Epidurálně: většinou směs bupivakainu } 0,1 \% \text { a sufentanilu } 0,5-1 \mu \mathrm{g} / \mathrm{ml} \text { podávaná } \\
\text { rychlostí } 5-12 \mathrm{ml} / \mathrm{h}^{* * * *}\end{array}$ \\
\hline
\end{tabular}

*při p.r. podání nemusí být dosaženo terapeutické hladiny, ${ }^{* *}$ nepodávat ve 3. trimestru gravidity pro riziko uzávěru Botallovy dučeje, ${ }^{* * *} v$ ČR dostupný pro i.v. infuzi i preparát obsahujicí navíc 30 mg centrálního myorelaxancia orfenadrinu, který pomáhá uvolňovat bolestivé reflexni spasmy kosterního svalstva po operaci (výhodné napríklad po operacích na páterii), ****pouze na monitorovaném lưžku

a zvracení, útlumu střevní peristaltiky) snížením jejich celkové dávky, nebo nahrazením opioidů jinou skupinou léků či lokoregionální analgezií, byt’ v mnoha prípadech se bez opioidů obejít nelze. Jednotlivými složkami multimodální systémové analgezie jsou následující látky (Tabulka 2).

Paracetamol (v angl. acetaminophen) je pokládán za základní lék používaný ve všech kombinacích $(13,14)$. Pro hodnocení analgetického účinku se používá pojem number needed to treat
(NNT), což je počet osob, které je třeba léčit, aby u jednoho došlo k alespoň 50\% snížení intenzity bolesti. NNT paracetamolu má hodnotu 5 (15). Výhodou paracetamolu je minimální ovlivnění hemokoagulace, dostupnost i v infuzní formě, teoretickou nevýhodou je jeho hepatotoxicita při 8-10násobném předávkování, nejčastěji u rizikových osob s nízkou hladinou glutathionu (pacienti s malnutricí, jaterním onemocněním, chronickým alkoholismem, dehydratací) (16). 
HLAVNí TÉMA

Metamizol ( $v$ angl. dipyrone) je $v$ ČR častou složkou multimodální analgezie na rozdíl od většiny ostatních zemí, tomu odpovídá i menší počet mezinárodních publikací. Podle metaanalýzy z r. 2017 (17) je NNT metamizolu 2,4; pozoruhodně málo, což může být dáno měřením především po stomatologických výkonech. Lék je v perioperačním období považován za bezpečný. Riziko agranulocytózy je minimální, závažné bývají anafylaktické/ anafylaktioidní reakce. Zvláštní opatrnosti je při intravenózním podávání věnovat rizikovým osobám (s anamnézou polyvalentní alergie, těžkého bronchiálního astmatu). Na našem pracovišti injekční formu i.v. podáváme zásadně v infuzi v trvání 30-60 minut. V některých prípadech (bolesti břicha) je výhodná kombinace metamizolu se spasmolytikem (pitofenon) (16).

Nesteroidní antiflogistika tvoří rozsáhlou skupinu léčiv, řada z nich (ibuprofen, diklofenak, ketoprofen, parecoxib) je dostupná v injekční formě a může být používána v bezprostředním pooperačním období. Jsou účinné na mírnou a střední bolest, zejména pokud je spojená se zánětem. Přes tuto zjevnou výhodu ji recentně jako součást multimodální analgezie někteří autoři nedoporučují. Na jedné straně stojí jejich analgetické účinky se snížením spotřeby opioidů o 15-55 \%, i jejich nežádoucích účinků - nauzey, zvracení (NNT = 15) a nadměrné sedace (NNT = 37). Na druhé straně jsou to nežádoucí účinky: riziko závažného krvácení (number needed to harm - NNH = 59) a u koxibů po kardiochirurgických operacích riziko renálního selhání (NNH = 73) (18). Závěrem většiny doporučení je, že pouhé snížení spotřeby opioidů není dostatečnou oporou pro využití látky jako doplňkového analgetika $(18,19)$. V každém prípadě je vhodné se nesteroidním analgetikům v terapii APB vyhnout při riziku krvácivých komplikací a př́tomnosti alergie, těžké hypertenze, kardiálního onemocnění, jaterní a renální insuficience.

Ketamin je v současnosti důležitou komponentou multimodální analgezie. V r. 2018 vyšla v USA společná doporučení 3 odborných společností o použití ketaminu v léčbě akutní (20) a chronické bolesti (21). Cílem obou doporučení je povzbudit lékaře k většímu používání ketaminu v běžné praxi a k omezení použití opioidů. Přes nedostatek kvalitních studií (většina doporučení je na úrovni B a C) je ketamin

Tab. 3. Dávkování opioidů při pacientem řizené analgezii - modifikováno podle (30)

\begin{tabular}{|l|l|l|}
\hline Lék & Jednotlivá dávka bolus & Bezpečnostní interval (min.) \\
\hline Morfin & $0,5-2,5 \mathrm{mg}$ & $5-10$ \\
\hline Fentanyl & $50-100 \mu \mathrm{g}$ & $3-10$ \\
\hline Sufentanil & $2,5-5 \mu \mathrm{g}$ & $3-10$ \\
\hline
\end{tabular}

Poznámka: kontinuální infuze na pozadi bolusového dávkováni se nedoporučuje pro riziko předávkování

Obr. 3. Prístroj pro pacientem rízenou analgezii (PCA)

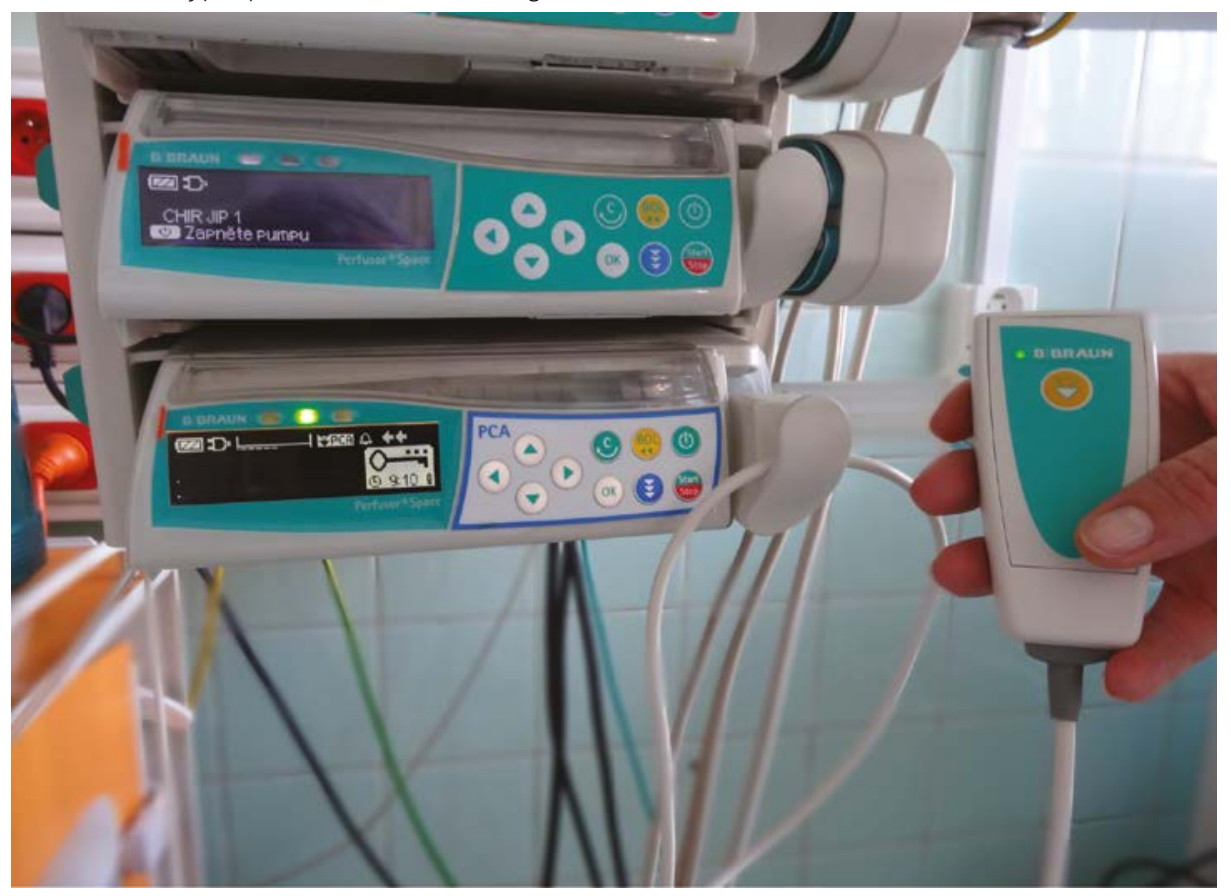

považován za bezpečný adjuvantní lék, jehož nežádoucí účinky jsou srovnatelné s placebem. Je zvláště výhodný u opioid-tolerantních pacientů a pacientů se syndromem spánkové apnoe. Doporučené dávky by neměly být vyšší než 0,35 mg/kg jako i. v. bolus, resp. kontinuálně do 1 mg/kg/h. Kontraindikací je závažné kardiovaskulární onemocnění, těhotenství, psychózy a zvýšený nitrolební a nitrooční tlak.

Opioidy tvoři i nadále základní složku terapie silné $A P B, z$ nich nejčastěji morfin, piritramid a na monitorovaných lůžcích fentanyl a sufentanil. Petidin je považován za obsoletní a používán by být již neměl. Nové látky, které by měly mít na opioidním receptoru analgetickou aktivitu, aniž by působily dechovou depresi (oliceridin, PZM21 a mitragynin) (22), nejsou zatím klinicky dostupné. Postupy zcela eliminující opioidy jsou omezeny na několik málo výzkumných pracovišt (23) a jasné výhody různých analgetických koktejlů z mnoha současně podaných látek nejsou jednoznačně potvrzené (4). Při podávání opioidů je důležité nekombinovat typické morfiniformní látky (působící převážně přes mí-receptor) s opioidními analgetiky ze skupiny smíšených agonis- tů/antagonistů jako je nalbufin či pentazocin (t.č. není v ČR registrován). Rovněž není vhodné při přetrvávající nedostatečné analgezii po podání silných opioidů doplňovat léčbu bolesti opioidy slabými (tramadol).

Výhodná je metoda pacientem kontrolované analgezie (PCA, obrázek 3). Metoda spočívá v samoobslužné aplikaci analgetika (nejčastěji opioidu) do žíly, nebo méně často směsi lokálního anestetika a opioidu do epidurálního prostoru (PCEA). Výsledkem je vyšší spokojenost pacientů a kvalitnější analgezie (19). Předávkování je bráněno vhodnou volbou jednotlivé dávky, bezpečnostním intervalem, kdy přístroj nedávkuje, i když se pacient pokouší o aplikaci, a často i maximálním objemem, který Ize aplikovat za časový interval 4 nebo 6 hodin (Tabulka 3). Kromě parenterálního podání jsou používané také méně invazivní cesty (sublinguální, nazální, transdermální pomocí iontoforézy). V ČR byl registrován fentanyl pro iontoforetickou PCA, ale registrace byla zrušena. Ostatní neinvazivní způsoby jsou v ČR registrovány pouze pro léčbu průlomové bolesti u dospělých pacientů již užívajících opioidy pro chronickou nádorovou 


\section{HLAVNÍ TÉMA}

bolest, ale v zahraničí je sublinguální forma sufentanilu metodou PCA pro APB registrovaná.

Adjuvantní léky jsou z mnoha rưzných lékových skupin, často jsou v léčbě APB podávány mimo schválené použití. Ačkoliv řada z nich byla intenzivně studována, pozitivní výsledky pocházejí zpravidla z malých studií, zatímco metaanalýzy a rozsáhlé prospektivní studie jejich účinnost většinou nepotvrdily. Velké množství prací bylo věnováno gabapentinoidům. Vedou k mírnému snížení spotřeby opioidů, ale nežádoucím účinkem je sedace, takže v současnosti panuje názor, že by používány být neměly $(24,25)$. Výzkum probíhá i u dalších skupin (alfa-2 sympatomimetika, magnezium, esmolol), výsledky zatím nejsou dostatečně přesvědčivé, aby mohly být doporučeny (19). U kolorektálních operací prokázal účinnost systémově podávaný lidokain (19). Běžné dávkování je iniciálně před začátkem operace 1,0-1,5 mg/kg i.v. a dále $0,02 \mathrm{mg} / \mathrm{kg} / \mathrm{min}$. po 24-48 hodin.

Lokální metody analgezie s použitím místních anestetik patří neoddělitelně k multimodální analgezii. Od centrálních přistupů (míšní svodné metody analgezie, blokáda velkých plexů) je vidět trend v používání stále perifernějších nervových blokád, které by bez ultrazvukové navigace byly dřive neproveditelné (26). Popis jednotlivých blokád a prístupů je mimo rozsah tohoto článku. Současně se prosazují systémy, které umožňují kontinuální proplach operační rány lokálním anestetikem (obrázek 4), prípadně pro dlouhodobý účinek speciálně upravené molekuly bupivakainu pro jednorázové infiltrační podání a morfinu pro epidurální podání (26).

Výběr konkrétní léčby APB je vhodné volit s ohledem na předpokládanou intenzitu bolesti u daného typu operace (procedure specific analgesia) a současně upravovat podle individuální odpovědi konkrétního pacienta.

\section{Pacienti léčení opioidy před operací a preemptivní analgezie}

$\checkmark$ současnosti se zvyšuje počet pacientů chronicky užívajících opioidy. U nich dochází ke vzniku tolerance a fyzické závislosti s rizikem rozvoje syndromu z vysazení při přerušení léčby nebo použití antidota, takže je zcela nezbytné zajistit pokračování léčby $v$ celém periope-

Obr. 4. Elastomerický dávkovač na kontinuální proplach rány lokáním anestetikem

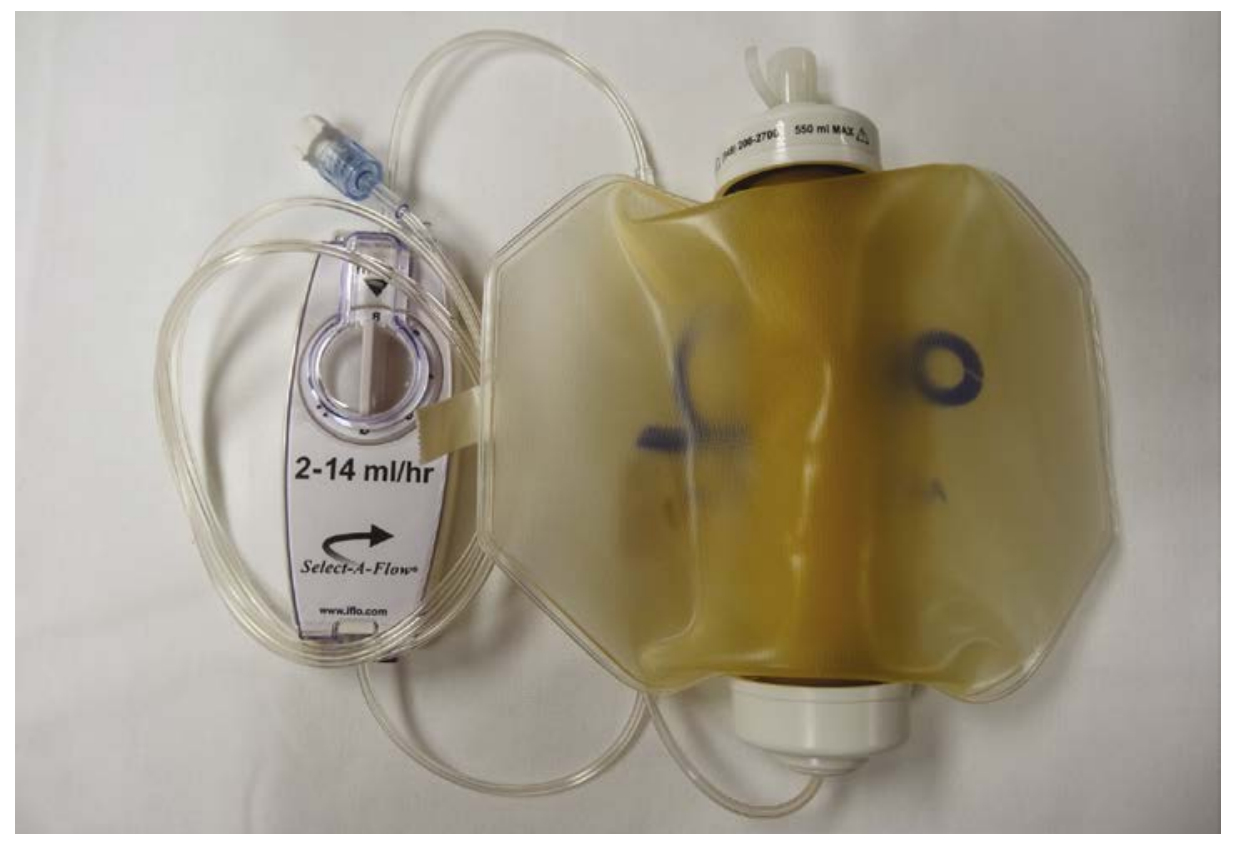

račním období. Náplastové lékové formy se ponechávají po celou dobu, perorální formy s postupným uvolňováním potom až do operace. Navíc je třeba počítat s tím, že spotřeba opioidů k zajištění perioperační analgezie bude u těchto pacientů vyšší, než u pacientů opioid-naivních. Je málo známo, že opioid-tolerantní pacienti mohou mít paradoxně vyšší riziko dechového útlumu než osoby opioid-naivní, protože tolerance na analgetické účinky opioidů vzniká rychleji než tolerance na útlum dechu (11). V prípadě, že operace i pooperační léčba bolesti jsou vedeny metodami místní anestezie, měla by být zajištěna bazální denní dávka opioidu k prevenci rozvoje abstinenčního syndromu. Ani při odstranění bolesti nelze vysadit opioidy náhle; dávku Ize postupně redukovat o cca 25 \% každé 3 dny, v některých prípadech výrazně pomaleji. Nesouvisí-li operace s chronickou bolestí, je třeba pacientovi zajistit pokračování v opioidní medikaci. U pacientů v odvykací léčbě volíme - pokud je to možné postupy neopioidní analgezie nebo regionální anestezie s použitím lokálního anestetika bez opioidu $(8,9)$.

Termín preemptivní analgezie vycházel z experimentu na zviŕeti, kdy použití analgezie ještě před vznikem bolesti vedlo ke snížení spotřeby analgetik; tj. stejná látka podaná pred operací byla účinnější než tatáž látka ve stejné dávce použitá až po začátku operace. Tento zpưsob měl zabránit periferní i centrální senzitizaci, ale v klinické praxi nebyly výsled- ky přesvědčivé, protože bolestivá stimulace pokračuje i po operaci a po odeznění účinku preemptivně podané látky (27). V současnosti je používán termín preventivní analgezie, který znamená trvalé potlačení bolestivé stimulace po celou dobu hojení (28).

\section{Závěr}

Léčba APB má kromě etického rozměru (odstranění zbytečného utrpení) i ten význam, že silná APB zvyšuje pooperační morbiditu (29, 30). Akutní bolest působí stimulaci sympatiku, což zvyšuje nároky na oběhový a dýchací systém, vede k hyperglykemii, katabolismu, nežádoucím způsobem ovlivňuje imunitní systém, zhoršuje spánek a obecně kvalitu života pacientů po jinak úspěšné operaci. V České republice nejsou dosud k dispozici přesná čísla, ale zvýšená morbidita a prodloužení pobytu pacientů na jednotkách intenzivní péče následkem nedostatečně léčené APB přináší s sebou i zvýšené náklady na léčbu. Terapie APB není záležitostí jedné odbornosti, ale jako celá péče o chirurgického pacienta je to problém multidisciplinární, vyžadující spolupráci lékařských i nelékařských zdravotnických pracovníků. Navíc je známo, že poskytnutí kvalitní pooperační analgezie je jenom jednou ze součástí celkového zlepšení péče o pacienty. K dalším patří mimo jiné prevence hypotermie, eliminace negativních faktorů okolního prostředí, časná orální nutrice, celková kvalita ošetřovatelské péče a časná dimise (30). 
HLAVNÍ TÉMA ।

PERIOPERAČNÍ LÉČBA BOLEST

\section{LITERATURA}

1. Fitzharris L. How ether transformed surgery from a race against the clock. Scientific American 2017. Dostupné on-line na https://www.scientificamerican.com/article/how-ether-transformed-surgery-from-a-race-against-the-clock/ 2. American Pain Society Quality of Care Committee. Quality improvement guidelines for the treatment of acute pain and cancer pain. JAMA 1995; 274: 1874-1880.

3. Joint Commission on Accreditation of healthcare organisations pain standards for 2001. Dostupné on-line (cit. 19. 1. 2019) na https://www.jointcommission.org/ assets/1/6/2001_Pain_Standards.pdf

4. Wardhan R, Chelly J. Recent advances in acute pain management: understanding the mechanisms of acute pain, the prescription of opioids, and the role of multimodal pain therapy. F1000Research 2017, 6(F1000 Faculty Rev): 2065. Dostupné on-line na https://f1000research.com/articles/6-2065/v1 5. Purdue guilty plea. 2007. Dostupné on-line na https://archive.org/stream/279028-purdue-guilty-plea/279028-purdue-guilty-plea_djvu.txt

6. United States of America v. The Purdue Frederick Company, Inc., et al. Dostupné on-line na http://www.vawd.uscourts.gov/opinions/jones/107cr00029.pdf

7. Chou R, Gordon DB, de Leon-Casasola OA, et al. Management of Postoperative Pain: A clinical practice guideline from the American Pain Society, the American Society of Regional Anesthesia and Pain Medicine, and the American Society of Anesthesiologists' Committee on Regional Anesthesia, Executive Committee, and Administrative Council. The Journal of Pain 2016; 17(2): 131-157.

8. Málek J, Ševčík P, et al. Postoperative Pain Management. Third updated edition. Mladá Fronta 2017. Dostupné on-line (cit. 8. 2. 2019) na https://www.wfsahq.org/components/ com_virtual_library/media/125136f77e1b7daf7565bd66530 26c35-Postoperative-Pain-Management-170518.pdf

9. Gabrhelík T, Málek J. Opioidy v léčbě pooperační bolesti. In: Kozák J, Lejčko J, Vrba I a kol. Opioidy. Praha: Mladá Fronta, 2018, s. 247-266.

10. Pogatzki-Zahn EM, Segelcke D, Schug SA. Postoperati- ve pain - from mechanisms to treatment. Pain Rep 2017; 2. 11. Hayhurst CJ, Durieux ME. Differential opioid tolerance and opioid-induced hyperalgesia. A clinical reality. Anesthesiolo gy 2016; 124(2): 483-485.

12. Fletcher $D$, Martinez V. Opioid-induced hyperalgesia in patients after surgery: a systematic review and a meta-analysis. British Journal of Anaesthesia 2014; 112(6): 991-1004.

13. Liang L, Cai Y, Li A, Ma C. The efficiency of intravenous acetaminophen for pain control following total knee and hip arthroplasty: a systematic review and meta-analysis. Medicine (Baltimore). 2017; 96(46): e8586.

14. Mitra S, Carlyle D, Kodumudi G, Kodomundi V, Vadivelu N. New advances in acute postoperative pain management. Curr Pain Headache Rep 2018; 22: 35. Dostupné on-line (cit. 19. 1. 2019) na https://doi.org/10.1007/s11916-018-0690-8 15. McNicol ED, Ferguson MC, Haroutounian S, Carr DB, Schumann R. Single dose intravenous paracetamol or intravenous propacetamol for postoperative pain. Cochrane database Syst rev. 2016; (5): CD007126.

16. SPC jednotlivých látek. Dostupné on-line (cit. 8. 2. 2019) na www.sukl.cz

17. Konijnenbelt-Peters J, van der Heijden C, Ekhart C, Bos J, Bruhn J, Kramers C. Metamizole (Dipyrone) as an alternative agent in postoperative analgesia in patients with contraindications for nonsteroidal anti-inflammatory drugs. Pain Pract 2017; 17(3): 402-408.

18. Elia N, Lysakowski C, Tramer MR. Does multimodal analgesia with acetaminophen, nonsteroidal antiinflammatory drugs, or selective cyclooxygenase-2 inhibitors and patient-controlled analgesia morphine offer advantages over morphine alone? Metaanalyses of randomized trials. Anesthesiology 2005; 103(6): 1296-1304

19. Rawal N. Current issues in postoperative pain management. Eur J Anaesthesiol 2016; 33: 160-170.

20. Schwenk ES, Viscusi ER, Buvanendran A, et al. Consensus guidelines on the use of intravenous ketamine infusions for acute pain management from the American Society of Regional Anesthesia and Pain Medicine, the American Academy of Pain Medicine, and the American Society of Anesthesiologists. Reg Anesth Pain Med 2018; 43(5): 456-466.

21. Cohen SP, Bhatia A, Buvanendran A, et al. Consensus guidelines on the use of intravenous ketamine infusions for chronic pain from the American Society of Regional Anesthesia and Pain Medicine, the American Academy of Pain Medicine, and the American Society of Anesthesiologists. Regional Anesthesia and Pain Medicine 2018; 43(5): 521-546. 22. Gan TJ. Poorly controlled postoperative pain: prevalence, consequences, and prevention. Journal of Pain Research 2017; 10: 2287-2298.

23. Lavand'homme P, Estebe J. Opioid free anesthesia: a different regard to anesthesia practice. Curr Opin Anaesthesiol. 2018; 31(5): 556-561.

24. Zhang J, Ho KY, Wang Y. Efficacy of pregabalin in acute postoperative pain: a meta-analysis. Br J Anaesth 2011 Apr 106(4): 454-462.

25. Fabritius ML, Geisler A, Petersen PL, et al. Gabapentin for post-operative pain management - a systematic review with meta-analyses and trial sequential analyses. Acta Anaesthesiol Scand 2016; 60(9): 1188-1208.

26. Graber R, Kraay M. Regional Anesthesia For Postoperative Pain Control. Medscape 2017. Dostupné on-line (cit. 19. 1. 2019) na https://emedicine.medscape.com/article/ 1268467-overview

27. Mishra AK, Afzal M, Mookerjee SS, Bandyopadhyay KH, Paul A. Pre-emptive analgesia: Recent trends and evidences. Indian J Pain 2013; 27: 114-120.

28. Rosero EB, Joshi GP. Preemptive, preventive, multimodal analgesia: What do they really mean? Plast. Reconstr. Surg 2014; 134(Supplement): 85S-93S.

29. Ševčík P, Málek J, Bejšovec D, et al. Doporučené postupy diagnostiky a terapie: Léčba akutní pooperační bolesti. Dostupné on-line (cit. 19. 1. 2019) na http://www.csarim.cz/ content/uploads/2018/11/doporuceny-postup-lecba-akutni-pooperacni-bolesti-2008.pdf

30. Málek J, Ševčík P a kol. Léčba pooperační bolesti. 3. aktualizované a doplněné vydání. Mladá fronta, Praha, 2014. 